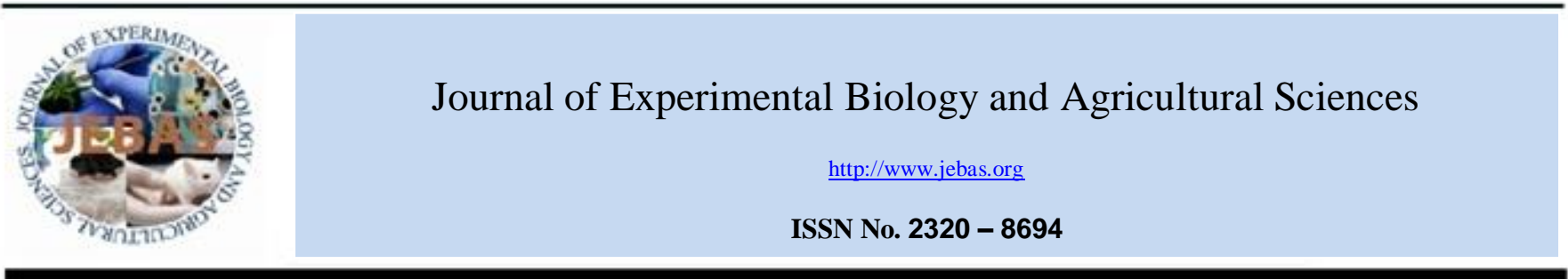

\title{
SCREENING OF SHORT DURATION RICE GENOTYPES FOR ZINC EFFICIENCY
}

\author{
Jegadeeswari $\mathrm{D}^{1 *}$, Chitdeshwari $\mathrm{T}^{1}$, Boominathan $\mathrm{P}^{2}$ \\ ${ }^{1}$ Department of Soil Science and Agricultural Chemistry, Tamil Nadu Agricultural University, Coimbatore, Tamil Nadu, India - 641003 \\ ${ }^{2}$ Department of Crop Physiology, Tamil Nadu Agricultural University, Coimbatore, Tamil Nadu, India - 641003
}

Received - December 01, 2018; Revision - January 06, 2019; Accepted - January 16, 2019

Available Online - February 5, 2019

DOI: http://dx.doi.org/10.18006/2019.7(1).25.33

\section{KEYWORDS \\ Rice genotypes \\ Screening \\ Zn use efficiency \\ Bio-fortification}

* Corresponding author

E-mail: jagadeeswari.d@tnau.ac.in (Jegadeeswari D)

Peer review under responsibility of Journal of Experimental Biology and Agricultural Sciences.

Production and Hosting by Horizon Publisher India [HPI] (http://www.horizonpublisherindia.in/).

All rights reserved.

\begin{abstract}
$\mathrm{Zn}(\mathrm{Zn})$ deficiency in tropical soils affects nutritional quality of food grains and to secure nutritional quality, one potential option is the 'agronomic bio-fortification' which depends mainly on genotypic efficiency to absorb and accumulate more of $\mathrm{Zn}$ into grains. To identify the rice genotypes having better ability to absorb and translocate more $\mathrm{Zn}$ into grains, a field experiment was conducted with 15 short duration rice genotypes on a $\mathrm{Zn}$ deficient sandy clay loam soil with and without $\mathrm{Zn}$ addition. A split plot design was adopted using $\mathrm{Zn}$ treatment in main plots, as $\mathrm{M}_{1}$ : control (only recommended dose of N,P, and $\mathrm{K}$ without $\mathrm{Zn})$ and $\mathrm{M}_{2}$ : recommended dose of $\mathrm{N}, \mathrm{P}$, and $\mathrm{K}$ with $\mathrm{Zn}\left(100 \mathrm{~kg} \mathrm{ZnSO}_{4} \mathrm{ha}^{-1}\right.$ as soil application $+0.5 \%$ as foliar application thrice at 50\% flowering, milk and dough stages) and the selected genotypes as sub plots. Results of present study revealed that, $\mathrm{Zn}$ application significantly increased the average grain yield (13.5\%) and grain $\mathrm{Zn}$ content (37 to $55 \%$ ) over control. The rice genotypes, CO 47 performed better with higher grain yield of 5980 and $6750 \mathrm{~kg} \mathrm{ha}^{-1}$ respectively under both with and without Zn fertilization. Higher grain yield index was noted with CO 47, and CO 51 (92.7) followed by ADT 45 (88.0) while the highest grain Zn uptake index was noted with CO 47 (40.4). Based on the yield and $\mathrm{Zn}$ uptake efficiency, the genotypes CO 47, CO 51, ADT 36, ADT 37, MDU 5, MDU 6, TKM 12, IR 50 were found efficient and responsive to $\mathrm{Zn}$ fertilization thus can be utilized for $\mathrm{Zn}$ bio-fortification. The rice genotypes TPS 5, Anna 4, CB 14508 are highly inefficient and susceptible to Zn deficiency which needs $\mathrm{Zn}$ fertilization without it the yield loss in unavoidable.
\end{abstract}

All the article published by Journal of Experimental Biology and Agricultural Sciences is licensed under a Creative Commons Attribution-NonCommercial 4.0 International License Based on a work at www.jebas.org.

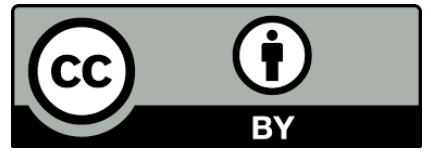




\section{Introduction}

Micronutrients such as Zinc ( $\mathrm{Zn})$, copper $(\mathrm{Cu})$, manganese $(\mathrm{Mn})$, iron $(\mathrm{Fe})$, boron $(\mathrm{B})$, and molybdenum $(\mathrm{Mo})$ are essential but required in small quantities for the growth and development of many plants (Alloway, 2008). These micronutrients are very crucial for plant, animal and human health and play a key role in various biochemical processes. It is estimated that $\mathrm{Zn}$ deficiency in Indian soils is likely to increase from 49 to $63 \%$ by 2025 . A substantial genetic variability in tolerance to $\mathrm{Zn}$ deficiency exists in many crops and this variability has been used significantly to improve the Zn acquisition by plants (Sudha \& Stalin, 2015a). The inherent soil micronutrients status mainly depends on the geological substrate and weathering processes (White \& Zasoski, 1999). Though the total concentration of micronutrients generally vary in soils due to diversity in parent materials, their availability to plants depends on $\mathrm{pH}$, organic matter, texture, soil moisture and clay mineralogy (Martens \& Lindsay 1990; Fageria, 2001). Generally, micronutrient content is high in the surfaces soils and decreases with depth (Gupta, 2005). The soil $\mathrm{pH}$ and oxidation-reduction conditions decide micronutrient form in which these are present in soil and determine their bioavailability by influencing fixation reactions (Fageria et al., 2011). Moreover, their content in the soils is also influenced by the type of cultivated crops which differ in their uptake of micronutrients. In the tropical soils of India, micronutrient deficiencies in soils is attributed to the larger removal from soil by fertilizer responsive high yielding crops, use of micronutrient free high analysis fertilizers, mono cropping, increased cropping intensity and reduction in the use of organic manures etc.

Zinc is considered as the fourth most important yield-limiting nutrient after, nitrogen, phosphorus and potassium (Shukla et al., 2018) and plays an important role in starch formation, synthesis of auxin and essential for the production of growth hormones like IAA. It also influences RNA levels and ribosome contents in cells, component of protein and chloroplast and also necessary for various enzymes that are responsible for driving many metabolic reactions in plants. In addition, $\mathrm{Zn}$ is a co-factor for many enzymes and proteins involved in cell division, nucleic acid metabolism and protein biosynthesis (Figueiredo, et al., 2012).

Continuous intensive cropping along with high yielding crop varieties has further aggravated the depletion of soil $\mathrm{Zn}$ leading to low $\mathrm{Zn}$ concentration in edible grains. The reported use efficiency of micronutrients in Indian soils seldom exceeds 5 per cent (Shukla et al., 2014). Reliance on cereal-based diets with low Zn may induce $\mathrm{Zn}$ deficiency in human beings resulted in serious health problems such as growth retardation, susceptibility to infectious diseases, hypogonadism, iron deficiency anemia, and poor birth outcome in pregnant women (Graham et al., 2000; Graham et al., 2012). The potential options to correct micronutrient deficiency in human beings may be food supplementation, food fortification or bio-fortification (White \& Broadley, 2009). "Agronomic bio-fortification" cannot be successfully achieved through the application of fertilizers nutrients which is proved effective in enriching micronutrients content in rice grain by controlling the availability of soil micronutrients (White \& Broadley, 2009). Studies showed that certain plant species, as well as their genotypes exhibit a significant genetic variation in their tolerance to $\mathrm{Zn}$ deficiency and this ability of a genotype to grow and yield well in a $\mathrm{Zn}$ deficient soil is termed as "Zn efficiency" (Hacisalihoglu \& Kochian, 2003). Genotypic differences for $\mathrm{Zn}$ use efficiency have been reported in several crops species (Rengel, 2005; Cakmak et al., 2010) and related to various mechanisms operating in the rhizosphere and within the plant system.

Rice is an important staple food and energy source for more than half of the world population, however, it is a poor source of essential micronutrients such as Fe and Zn (Welch, 2008; Tripathy et al., 2017). It is highly sensitive crop to Zn deficiency with drastic yield reduction and lesser $\mathrm{Zn}$ concentration in the grains yield when $\mathrm{Zn}$ is limited in soils. Application of $\mathrm{Zn}$ fertilizers is essential for keeping sufficient available $\mathrm{Zn}$ in soil solution and maintaining adequate transport during critical growth stages of crop which leads increased grain $\mathrm{Zn}$ concentration to a considerable amount. Thus the present study was proposed to study the effect of $\mathrm{Zn}$ fertilization on grain yield and $\mathrm{Zn}$ content in rice and to identify the $\mathrm{Zn}$ uptake efficient short duration rice genotypes for bio-fortification.

\section{Materials and Methods}

\subsection{Experimental site}

Field experiment was conducted in naturally $\mathrm{Zn}$ deficient soil at wetland farms of Tamil Nadu Agricultural University, Coimbatore. The farm is situated at an altitude of $426.72 \mathrm{~m}$ above MSL in the Western agro climatic Zone of Tamil Nadu at $11^{\circ}$ North latitude and $77^{\circ}$ East longitude.

\subsection{Climatic condition}

Annual rainfall of $641 \mathrm{~mm}$ in 37 rainy days and cropping period rainfall of $302 \mathrm{~mm}$ in 18 rainy days were recorded during 2016-17 at the principal observatory, Agro Climate Research Centre, Tamil Nadu Agricultural University, Coimbatore. The North East Monsoon (NEM) contributes $375 \mathrm{~mm}$ of rainfall. The relative humidity ranged from 26 to 94 per cent with mean sunshine hours of 7.4 hours. The mean maximum and minimum temperatures prevailed during the cropping period was $30.3^{\circ} \mathrm{C}$ and $21.3{ }^{\circ} \mathrm{C}$ which were favourable for growth and development of rice crop (AMFU - Coimbatore, 2017). 


\subsection{Soil characteristics}

Surface soil samples were drawn from 0-15 cm air dried, crushed and passed through two $\mathrm{mm}$ sieve. The initial soil properties were analyzed as per the standard methods which were furnished in table 1 . The soil of the experimental field was slightly alkaline in $\mathrm{pH}$ (8.32) with low salt $\left(0.30 \mathrm{dS} \mathrm{m}^{-1}\right)$ and available $\mathrm{N}$ status (222 $\left.\mathrm{kg} \mathrm{ha}^{-1}\right)$, medium organic carbon $\left(5.60 \mathrm{~g} \mathrm{ha}^{-1}\right)$, high in available $\mathrm{P}$ $\left(24.0 \mathrm{~kg} \mathrm{ha}^{-1}\right)$ and $\mathrm{K}\left(410 \mathrm{~kg} \mathrm{ha}^{-1}\right)$. The soil of the study area was deficient to $\mathrm{Zn}\left(0.98 \mathrm{mg} \mathrm{ha}{ }^{-1}\right)$ but sufficient for other micronutrients.

\subsection{Experiment details}

The experiment was conducted during the kharif season of 2017 at wetland farms of Tamil Nadu Agricultural University, Coimbatore to screen short duration rice genotypes (15 nos.) for higher grain $\mathrm{Zn}$ content and $\mathrm{Zn}$ efficiency using soil and foliar $\mathrm{Zn}$ fertilization practices. Rice genotypes included in the study were ADT 36, ADT 37, ADT 43, ADT (R) 45, MDU 5, MDU 6, CO 47, CO 51, TPS 5, ASD 16, TKM 12, Anna (R) 4, IR 50, CB 14508 and Shabhagithan. Two $\mathrm{Zn}$ treatments viz, $\mathrm{M}_{1}$ : NPK Control (150: 50: $50 \mathrm{~kg} \mathrm{NPK} \mathrm{ha}{ }^{-1}$ ) and $\mathrm{M}_{2}: \mathrm{M} 1+\mathrm{Zn}$ at $100 \mathrm{~kg} \mathrm{ZnSO}_{4} \mathrm{ha}^{-1}$ as soil application $+0.5 \%$ as thrice foliar application at $50 \%$ flowering, milk and dough stages. The fertilizers were applied basally and the crop was grown to maturity and harvested. The grain and straw yield of crop, Zn content and uptake was recorded besides measuring the yield and growth attributes. The post harvest soil and plant samples were collected and analysed for $\mathrm{Zn}$ status using atomic absorption spectrophotometer (Lindsay \& Norvell, 1978). The $\mathrm{Zn}$ efficient and inefficient rice genotypes were identified using uptake and yield efficiency indices marked on $\mathrm{X}$ and $\mathrm{Y}$ axis, by drawing a scattered diagram (Graham et al.,1992; Fageria \& Baligar, 1993). All the data were analysed by using OPSTAT model (Sheoran et al., 1998)
A perpendicular and parallel line to $\mathrm{X}$ axis were drawn with an average yield and uptake efficiency to divide the scattered diagram so as to classify the genotypes into four groups viz. efficient and responsive (ER), efficient and non responsive (ENR), inefficient and responsive (IER) and inefficient and non responsive (IENR) as described by Graham et al. (1992) and Fageria et al (2008). The ER genotypes have high yield as well as high uptake efficiency index, ENR genotypes have high yield and low uptake efficiency index, IER genotypes have low yield and high uptake efficiency index and IENR have low yield as well as low uptake efficiency index. The efficient and responsive genotypes would be most suitable for enriching $\mathrm{Zn}$ in grains through biofortifictaion.

\section{Results and Discussion}

\subsection{Effect of Zn fertilization on Yield}

Spectacular differences were witnessed on the grain and straw yield of rice owing to the interaction between the $\mathrm{Zn}$ fertilization and genotypes (Table 2). The grain and straw yield differed from 4492 to $7200 \mathrm{~kg}$ and 6980 to $9297 \mathrm{~kg} \mathrm{ha}^{-1}$ respectively. Application of $150: 50: 50 \mathrm{~kg}+100 \mathrm{~kg} \mathrm{ZnSO}_{4} \mathrm{ha}^{-1}$ as soil application $+0.5 \%$ as foliar application thrice at $50 \%$ flowering, milk and dough stages recorded the highest grain and straw yield of $7200 \mathrm{~kg}$ and $9297 \mathrm{~kg} \mathrm{ha}^{-1}$. This increase in yield might be attributed to the greater influence of $\mathrm{Zn}$ on basic plant life processes, such as nitrogen metabolism (uptake of nitrogen and protein quality) and photosynthesis (chlorophyll synthesis and carbonic anhydrase activity) (Hazra et al., 2015; Kumar et al., 2018). The genotype CO 47 registered the highest grain yield in both control $\left(6000 \mathrm{~kg} \mathrm{ha}^{-1}\right)$ and $\mathrm{Zn}$ applied plots $\left(7200 \mathrm{~kg} \mathrm{ha}^{-1}\right)$, while the lowest grain yield was recorded in IR 50 in control $\left(4500 \mathrm{~kg} \mathrm{ha}^{-1}\right)$ and $\mathrm{Zn}$ applied treatments $\left(5142 \mathrm{~kg} \mathrm{ha}^{-1}\right)$. However with regard to straw yield, highest straw yield was recorded with

Table 1 Details of analytical procedures employed in soil analysis

\begin{tabular}{|ccc|}
\hline Estimations & Procedure & Reference \\
\hline Soil reaction $(\mathrm{pH})$ & Physico-chemical properties & Jackson (1973) \\
\hline Electrical conductivity (EC) & $1: 2.5$ soil water suspension & Jackson (1973) \\
\hline Organic carbon & $1: 2.5$ soil water suspension & Walkley \& Black (1934) \\
\hline Available nitrogen & Chemical properties & Subbiah \& Asija (1956) \\
\hline Available phosphorus & Chromic acid wet digestion & Olsen et al. (1954) \\
\hline Available potassium & Alkaline permanganate method & Stanford \& English (1949) \\
\hline DTPA micronutrients & $0.5 \mathrm{M} \mathrm{NaHCO}_{3}(\mathrm{pH}-8.5)$ & Lindsay \& Norvell (1978) \\
\hline
\end{tabular}

Journal of Experimental Biology and Agricultural Sciences http://www.jebas.org 
Table 2 Effect of $\mathrm{Zn}$ fertilization on grain and straw yield of rice genotypes

\begin{tabular}{|c|c|c|c|c|c|c|}
\hline \multirow{3}{*}{ Genotypes } & \multicolumn{6}{|c|}{ Yield $\left(\mathrm{kg} \mathrm{ha}^{-1}\right)$} \\
\hline & \multicolumn{3}{|c|}{ Grain } & \multicolumn{3}{|c|}{ Straw } \\
\hline & $(-\mathrm{Zn})$ & \multicolumn{2}{|c|}{$(+\mathrm{Zn})$} & $(-\mathrm{Zn})$ & \multicolumn{2}{|c|}{$(+\mathrm{Zn})$} \\
\hline Anna (R) 4 & 5417 & \multicolumn{2}{|c|}{6292} & 8063 & \multicolumn{2}{|c|}{8605} \\
\hline ADT 37 & 5083 & \multicolumn{2}{|c|}{5583} & 8147 & \multicolumn{2}{|c|}{8830} \\
\hline MDU 5 & 4500 & \multicolumn{2}{|c|}{5142} & 7147 & \multicolumn{2}{|c|}{7788} \\
\hline $\mathrm{CO} 47$ & 6000 & \multicolumn{2}{|c|}{7200} & 7480 & \multicolumn{2}{|c|}{9297} \\
\hline $\mathrm{CO} 51$ & 5850 & \multicolumn{2}{|c|}{6733} & 8230 & \multicolumn{2}{|c|}{9205} \\
\hline TPS 5 & 5000 & \multicolumn{2}{|c|}{6583} & 8047 & \multicolumn{2}{|c|}{8788} \\
\hline CB 14508 & 5317 & \multicolumn{2}{|c|}{6092} & 7855 & \multicolumn{2}{|c|}{8897} \\
\hline ASD 16 & 5167 & \multicolumn{2}{|c|}{6200} & 8147 & \multicolumn{2}{|c|}{8997} \\
\hline ADT 43 & 4850 & \multicolumn{2}{|c|}{5833} & 7880 & \multicolumn{2}{|c|}{8880} \\
\hline ADT 36 & 4667 & \multicolumn{2}{|c|}{5250} & 6980 & \multicolumn{2}{|c|}{7747} \\
\hline TKM 12 & 5142 & \multicolumn{2}{|c|}{5483} & 8038 & \multicolumn{2}{|c|}{9097} \\
\hline Shabhagithan & 4892 & \multicolumn{2}{|c|}{5750} & 7680 & \multicolumn{2}{|c|}{8705} \\
\hline IR 50 & 4492 & \multicolumn{2}{|c|}{5183} & 7597 & \multicolumn{2}{|c|}{8030} \\
\hline ADT (R) 45 & 5025 & \multicolumn{2}{|c|}{5708} & 7705 & \multicolumn{2}{|c|}{8063} \\
\hline MDU 6 & 5275 & & & 7630 & & \\
\hline Mean & 5112 & & & 8063 & & \\
\hline & $\mathrm{SE}(\mathrm{d})$ & $\mathrm{CD}(\mathrm{P}=0.05)$ & $\mathrm{SE}(\mathrm{m})$ & $\mathrm{SE}(\mathrm{d})$ & $\mathrm{CD}(\mathrm{P}=0.05)$ & $\mathrm{SE}(\mathrm{m})$ \\
\hline $\mathrm{M}$ & 56.4 & 113.2 & 39.9 & 55.5 & 111.4 & 39.3 \\
\hline $\mathrm{V}$ & 154.5 & 310.1 & 109.2 & 152.2 & 305.2 & 107.6 \\
\hline M X V & 218.5 & 438.6 & 154.5 & 215.1 & 431.7 & 152.1 \\
\hline
\end{tabular}

$\mathrm{M}=$ Zn application $\quad \mathrm{V}=$ Rice genotypes

CO 47 and the lowest yield was evident in MDU 5. The overall data revealed $13.5 \%$ increase in grain yield and 11 per cent increase in straw yield due to $\mathrm{Zn}$ application over NPK alone and the yield increase in genotypes might be due to increased activity of enzymes and auxin metabolism in the plant which was reported by Sudha \& Stalin (2015a).

\subsection{Effect of $\mathrm{Zn}$ fertilization on $\mathrm{Zn}$ content}

Crop species have differential micronutrient density in grains when grown under similar conditions and the $\mathrm{Zn}$ concentration ranged from 11.5 to $37.2 \mathrm{mg} \mathrm{kg}^{-1}$ and 22.8 to $41.4 \mathrm{mg} \mathrm{kg}^{-1}$ in whole rice grains and straw respectively in $\mathrm{Zn}$ applied treatment and the increase in $\mathrm{Zn}$ content was 37 to 55 per cent over control. In the present study also genotypes differed significantly in $\mathrm{Zn}$ absorption and $\mathrm{CO} 47$ recorded the maximum $\mathrm{Zn}$ concentration in both grain and straw (37.2 and $41.4 \mathrm{mg} \mathrm{kg}^{-1}$ ) while the lowest $\mathrm{Zn}$ content was recorded in CB $14508\left(11.5 \mathrm{mg} \mathrm{kg}^{-1}\right)$ and TPS 5 $\left(22.8 \mathrm{mg} \mathrm{kg}^{-1}\right)$ in grain and straw respectively (Table 3$)$. It was statistically at par with CO 51(35.6 and $40.7 \mathrm{mg} \mathrm{kg}^{-1}$ ) and ASD 16 (35.4 and $40.1 \mathrm{mg} \mathrm{kg}^{-1}$ ) in grain and straw $\mathrm{Zn}$ contents respectively. The difference in micronutrient concentration in rice genotypes may be attributed to micronutrient loading in grains and according to Impa et al. (2013), some genotypes showed continued root uptake which is the predominant source of $\mathrm{Zn}$ loading in grain, whereas in some genotypes, net remobilization of $\mathrm{Zn}$ from shoot and root to grain was predominant. Further, the difference was also might be due to genotype and environment interaction, water management and soil factors like $\mathrm{pH}, \mathrm{EC}$, organic carbon, phosphorus and micronutrient availability (Sudha \& Stalin, 2015a). Increased root proliferation further increased the $\mathrm{Zn}$ uptake, enhanced synthesis of carbohydrates and its transport to grain (Sudha \& Stalin, 2015b; Tripathy et al., 2017). 
Table 3 Effect of $\mathrm{Zn}$ fertilization on $\mathrm{Zn}$ content in rice genotypes

\begin{tabular}{|c|c|c|c|c|c|c|c|}
\hline \multirow{3}{*}{ Genotypes } & \multicolumn{7}{|c|}{$\mathrm{Zn}$ content $\left(\mathrm{mg} \mathrm{kg}^{-1}\right)$} \\
\hline & \multicolumn{3}{|c|}{ Grain } & \multicolumn{4}{|c|}{ Straw } \\
\hline & $(-\mathrm{Zn})$ & \multicolumn{2}{|c|}{$(+\mathrm{Zn})$} & $(-\mathrm{Zn})$ & \multicolumn{3}{|c|}{$(+\mathrm{Zn})$} \\
\hline Anna (R) 4 & 14.1 & \multicolumn{2}{|c|}{34.5} & 25.4 & \multicolumn{3}{|c|}{36.4} \\
\hline ADT 37 & 14.8 & \multicolumn{2}{|c|}{34.3} & 27.9 & \multicolumn{3}{|c|}{38.9} \\
\hline MDU 5 & 14.9 & \multicolumn{2}{|c|}{33.7} & 29.2 & \multicolumn{3}{|c|}{38.7} \\
\hline $\mathrm{CO} 47$ & 16.2 & \multicolumn{2}{|c|}{37.2} & 30.4 & \multicolumn{3}{|c|}{41.4} \\
\hline CO 51 & 14.9 & \multicolumn{2}{|c|}{35.6} & 24.8 & \multicolumn{3}{|c|}{40.7} \\
\hline TPS 5 & 11.6 & \multicolumn{2}{|c|}{33.5} & 22.8 & \multicolumn{3}{|c|}{36.8} \\
\hline CB 14508 & 11.5 & \multicolumn{2}{|c|}{18.3} & 24.8 & \multicolumn{3}{|c|}{37.6} \\
\hline ASD 16 & 15.6 & \multicolumn{2}{|c|}{35.4} & 29.2 & \multicolumn{3}{|c|}{40.1} \\
\hline ADT 43 & 15.1 & \multicolumn{2}{|c|}{32.5} & 25.8 & \multicolumn{3}{|c|}{36.8} \\
\hline ADT 36 & 12.6 & \multicolumn{2}{|c|}{30.0} & 26.2 & \multicolumn{3}{|c|}{37.2} \\
\hline TKM 12 & 14.4 & \multicolumn{2}{|c|}{34.2} & 30.2 & \multicolumn{3}{|c|}{38.4} \\
\hline Shabhagithan & 12.7 & \multicolumn{2}{|c|}{31.1} & 23.4 & \multicolumn{3}{|c|}{36.4} \\
\hline IR 50 & 14.2 & \multicolumn{2}{|c|}{31.7} & 35.0 & \multicolumn{3}{|c|}{34.2} \\
\hline ADT (R) 45 & 11.8 & \multicolumn{2}{|c|}{34.5} & 23.4 & \multicolumn{3}{|c|}{35.8} \\
\hline MDU 6 & 14.8 & & & 27.4 & & 33.5 & \\
\hline Mean & 13.9 & & & 27.1 & & 37.5 & \\
\hline & $\mathrm{SE}(\mathrm{d})$ & $\mathrm{CD}(\mathrm{P}=0.05)$ & $\mathrm{SE}(\mathrm{m})$ & $\mathrm{SE}(\mathrm{d})$ & $\mathrm{CD}(\mathrm{P}=0.05)$ & & $\mathrm{SE}(\mathrm{m})$ \\
\hline M & 0.36 & 0.72 & 0.25 & 0.41 & 0.82 & & 0.29 \\
\hline V & 0.98 & 1.98 & 0.69 & 1.13 & 2.26 & & 0.80 \\
\hline M X V & 1.39 & 2.80 & 0.98 & 1.59 & 3.20 & & 1.13 \\
\hline
\end{tabular}

$\mathrm{M}=\mathrm{Zn}$ application $\mathrm{V}=$ Rice genotypes

\subsection{Effect of Zn fertilization on Zn uptake}

$\mathrm{Zn}$ application had positive influence on the $\mathrm{Zn}$ uptake by rice grains varied from 58 to $96.6 \mathrm{~g} \mathrm{ha}^{-1}$ in control and 153 to 269 $\mathrm{g} \mathrm{ha}^{-1}$ in $\mathrm{Zn}$ applied plot in grain yield while in straw it ranged from 179 to 242 in control and from 274 to $385 \mathrm{~g} \mathrm{ha}^{-1}$ in $\mathrm{Zn}$ applied treatment (Table 4). Genotypes exerted their differential response on $\mathrm{Zn}$ removal, in which $\mathrm{CO} 47$ recorded higher $\mathrm{Zn}$ uptake (269 and $385 \mathrm{~g} \mathrm{ha}^{-1}$ ) and the lowest $\mathrm{Zn}$ uptake was witnessed in IR50 in both grain and straw (153 and $274 \mathrm{~g} \mathrm{ha}^{-1}$ ). Total $\mathrm{Zn}$ uptake by rice genotypes ranged from 241 to $324 \mathrm{~g} \mathrm{ha}^{-1}$ in control treatment and 428 to $654 \mathrm{~g} \mathrm{ha}^{-1}$ in $\mathrm{Zn}$ applied treatment. The increased in $\mathrm{Zn}$ uptake could be attributed to better $\mathrm{Zn}$ absorption and root to shoot transport by $\mathrm{Zn}$ efficient genotypes and also probably due to more efficient transport system such as ion channel or ion pump, compared with the $\mathrm{Zn}$-inefficient genotypes (Malewar et al., 1993; Kumar et al., 2018).

\subsection{Zn Efficiency}

To assess the $\mathrm{Zn}$ efficiency of rice genotypes, yield and $\mathrm{Zn}$ uptake index was worked out by taking the ratio between yield and uptake in control and $\mathrm{Zn}$ applied treatments (Figure 1). The grain yield index varied from 76 to 92.7 , grain $\mathrm{Zn}$ index ranges from 34.6 to 46.5 and grain $\mathrm{Zn}$ uptake index varied from 26.3 to 40.4 . The results showed that, $\mathrm{CO} 47$ and CO 51 had higher grain yield index (92.7) followed by ADT 45 (88.0) while the highest grain $\mathrm{Zn}$ uptake index was noted with CO 47 (40.4). The lowest grain yield index of 76.0 and grain $\mathrm{Zn}$ uptake index of 26.3 were recorded in TPS 5, whereas the lowest grain $\mathrm{Zn}$ index of 34.2 was noticed in ADT 45. This was perhaps due to the abundant supply of $\mathrm{Zn}$ nutrition and balanced NPK, which increased the protoplasmic constituents, accelerates the process of cell division and elongation, photosynthesis processes, respiration, nitrogen metabolism-protein synthesis, other biochemical and physiological activates (Sudha \& Stalin, 2015a). 
Table 4 Effect of $\mathrm{Zn}$ fertilization on the $\mathrm{Zn}$ uptake by rice genotypes

\begin{tabular}{|c|c|c|c|c|c|c|c|c|c|}
\hline \multirow[t]{2}{*}{ Genotypes } & \multicolumn{9}{|c|}{ Zn uptake $\left(\mathrm{g} \mathrm{kg}^{-1}\right)$} \\
\hline & $(-\mathrm{Zn})$ & & & $(-\mathrm{Zn})$ & & & $(-\mathrm{Zn})$ & & \\
\hline Anna (R) 4 & 77.0 & & & 204 & & & 282 & & \\
\hline ADT 37 & 74.0 & & & 227 & & & 302 & & \\
\hline MDU 5 & 67.3 & & & 208 & & & 276 & & \\
\hline $\mathrm{CO} 47$ & 96.6 & & & 227 & & & 324 & & \\
\hline CO 51 & 87.9 & & & 204 & & & 292 & & \\
\hline TPS 5 & 58.0 & & & 183 & & & 241 & & \\
\hline CB 14508 & 60.7 & & & 195 & & & 256 & & \\
\hline ASD 16 & 81.1 & & & 236 & & & 318 & & \\
\hline ADT 43 & 72.1 & & & 203 & & & 275 & & \\
\hline ADT 36 & 58.8 & & & 182 & & & 242 & & \\
\hline TKM 12 & 74.6 & & & 242 & & & 317 & & \\
\hline Shabhagithan & 72.3 & & & 179 & & & 252 & & \\
\hline IR 50 & 61.8 & & & 271 & & & 333 & & \\
\hline ADT (R) 45 & 58.6 & & & 180 & & & 239 & & \\
\hline MDU 6 & 78.0 & & & 209 & & & 287 & & \\
\hline Mean & 71.9 & & & 210 & & & 282 & & \\
\hline & $\mathrm{SE}(\mathrm{d})$ & $\begin{array}{c}C D \\
(P=0.05)\end{array}$ & $\mathrm{SE}(\mathrm{m})$ & $\mathrm{SE}(\mathrm{d})$ & $\begin{array}{c}C D \\
(P=0.05)\end{array}$ & $\mathrm{SE}(\mathrm{m})$ & $\mathrm{SE}(\mathrm{d})$ & $\begin{array}{c}C D \\
(P=0.05)\end{array}$ & $\mathrm{SE}(\mathrm{m})$ \\
\hline M & 2.28 & 4.50 & 1.61 & 4.14 & 8.32 & 2.93 & 4.97 & 9.98 & 3.51 \\
\hline V & 6.24 & 12.5 & 4.41 & 11.3 & 22.7 & 8.02 & 13.6 & 27.3 & 9.63 \\
\hline M X V & 8.83 & 17.7 & 6.24 & 16.1 & 32.2 & 11.3 & 19.2 & 38.6 & 13.6 \\
\hline
\end{tabular}

$\mathrm{M}=\mathrm{Zn}$ application $\quad \mathrm{V}=$ Rice genotypes

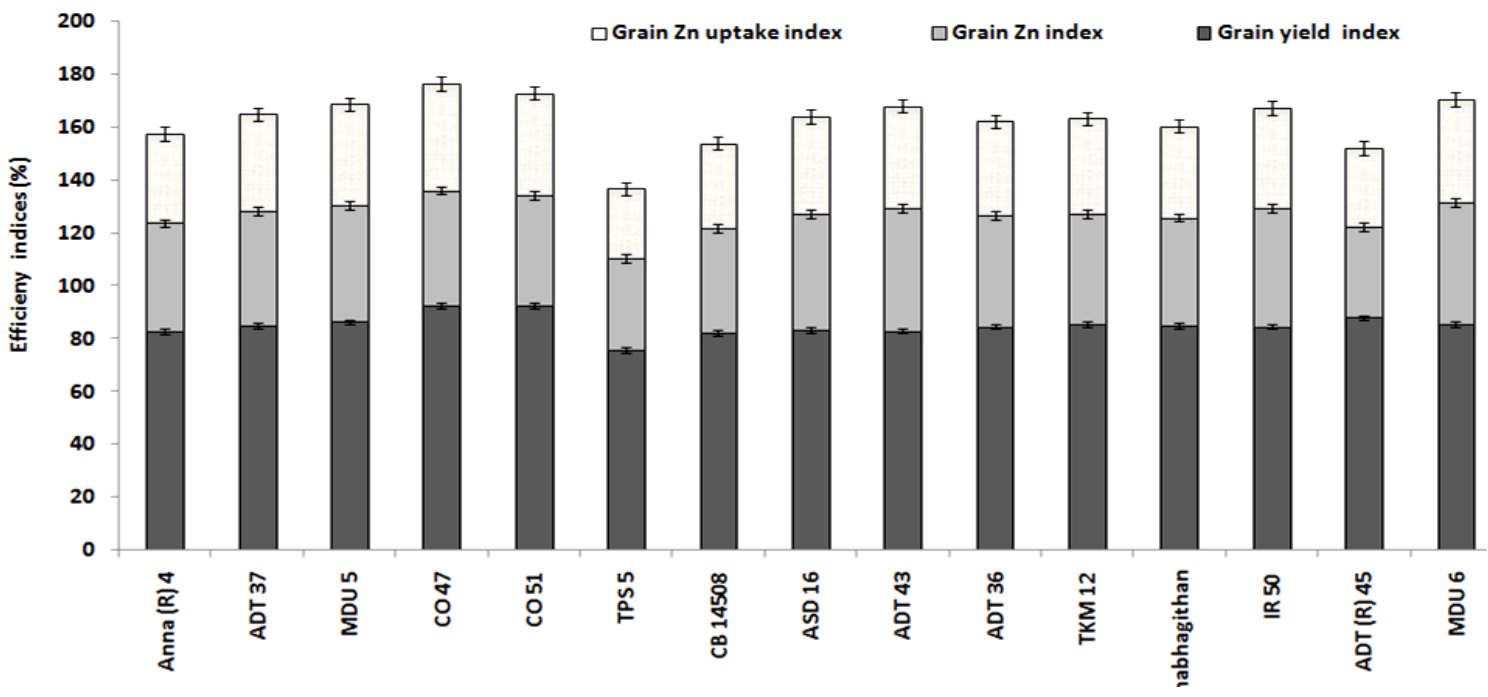

Figure 1 Grain yield and $\mathrm{Zn}$ uptake indices in rice grain

Journal of Experimental Biology and Agricultural Sciences http://www.jebas.org 
Table 5 Genotypes categorization based on yield and uptake efficiency

Genotypes Responsive

ADT 36, ADT 37, MDU 5, MDU 6, Co 47,

Efficient
CO 51, TKM 12, IR 50

ADT 43, ASD 16
Non responsive

ADT 45, Shabhagithan

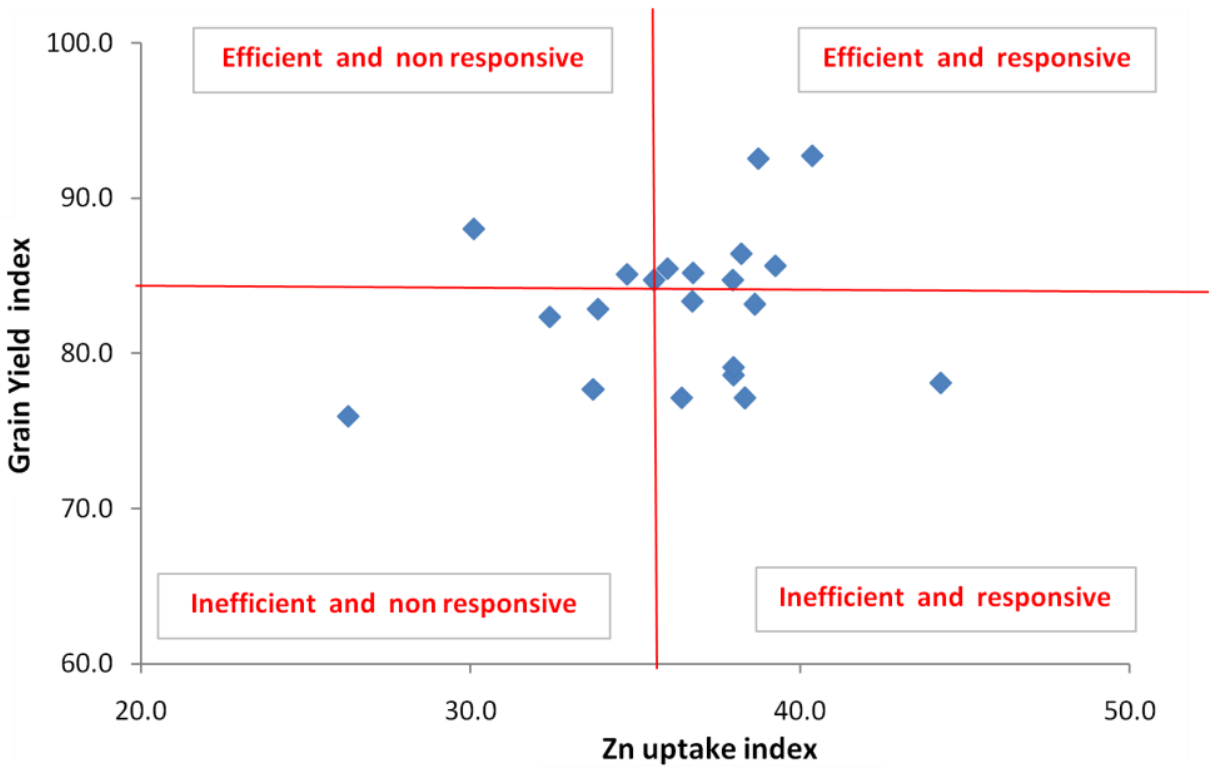

Figure 2 Grain Yield and uptake efficiency index of rice genotypes

The $\mathrm{Zn}$ uptake and efficiency varied widely among the genotypes which might be due to the ability of rice genotypes to increased $\mathrm{Zn}$ availability in the rhizosphere for subsequent uptake by releasing active $\mathrm{Zn}$ mobilizing substance such as phytosiderophores. Similar results with the resistant rice varieties under $\mathrm{Zn}$ stress condition in extracting $\mathrm{Zn}$ from complex and organically bound $\mathrm{Zn}$ forms was reported by Jin et al. (2008), However the susceptible varieties absorbed $\mathrm{Zn}$ only from readily available sources.

Based on the yield and $\mathrm{Zn}$ uptake efficiency, grouping of genotypes was made into efficient responsive, efficient non responsive, inefficient responsive and inefficient non responsive (Table $5 \&$ Figure 2) as per the classification of Fageria \& Baligar (1993) for nutrient use efficiency and average yield at low $\mathrm{Zn}$ supply. The first group comprised of efficient and responsive genotypes that produced more than the average yield of all the genotypes under $\mathrm{Zn}$ deficiency condition and their $\mathrm{Zn}$ efficiency was also higher than the average efficiency. Among the genotypes it was found that genotypes ADT 36, ADT 37, MDU 5, MDU 6, Co 47, CO 5, TKM 12 and IR 50 were grouped under efficient responsive.

The second group of efficient and non-responsive genotypes produced more than average yield at low $\mathrm{Zn}$ supply but response to $\mathrm{Zn}$ application was lower than the average. The genotypes ADT 45 and Shabhagithan are fund to be efficient non responsive. Third category, inefficient and responsive genotypes which produced less than average yield, but their response to $\mathrm{Zn}$ application was above the average, The genotypes falls this category are ADT 43 and ASD 16 and the fourth group of genotypes produced less than average yield at low $\mathrm{Zn}$ level and also less than average response to added $\mathrm{Zn}$. These genotypes are inefficient and non-responsive. The genotypes, TPS 5, Anna 4 and CB 14508 were grouped under inefficient non responsive genotypes. This indicates that genotypes with high efficiency are desired as they will be efficient scavengers of $\mathrm{Zn}$ under low level of $\mathrm{Zn}$ supply. Similar findings were reported by Kumar et al., (2018) in rice. 


\section{Conclusions}

The present investigation is concluded that, basal soil application of 150: $50: 50 \mathrm{~kg} \mathrm{NPK}+100 \mathrm{~kg} \mathrm{ZnSO}_{4} \mathrm{ha}^{-1}$ along with $0.5 \%$ as foliar spray thrice during $50 \%$ flowering, milk and dough stages of the rice crop significantly increased the rice grain and straw yield, $\mathrm{Zn}$ content and its uptake. Based on the efficiency indices, the genotypes, CO 47, CO 51, ADT 36, ADT 37, MDU 5, MDU 6, TKM 12, IR 50 were found efficient and responsive to $\mathrm{Zn}$ fertilization thus can be utilized for bio-fortification of $\mathrm{Zn}$. The genotypes ADT 45 and Shabhagithan are found to be $\mathrm{Zn}$ efficient but non-responsive to $\mathrm{Zn}$ application thus indicates that they are genetically efficient to utilize the native soil $\mathrm{Zn}$ thus suitable for $\mathrm{Zn}$ low condition. The rice genotypes TPS 5, Anna 4, CB 14508 are highly inefficient and susceptible to $\mathrm{Zn}$ deficiency.

\section{Acknowledgement}

The authors gratefully acknowledge Tamil Nadu Agricultural University for implementing the project by providing sufficient facilities.

\section{Conflict of interest}

The corresponding author declares that there is no conflict of interest.

\section{References}

Alloway BJ (2008) Zinc in soils and crop nutrition, $2^{\text {nd }}$ edition, International zinc association, Brussels, Belgium and IFA Paris, France.

AMFU - Coimbatore (2017) Annual report of Agrometerological field unit, Agro climate research centre, Tamil Nadu Agricultural University, Coimbatore.

Cakmak I, Kalayai M, Kaya Y (2010) Biofortification and localization of $\mathrm{Zn}$ in wheat grain. Journal Agriculture and Food Chemistry 58:9092-9102.

Fageria NK (2001) Screening method of lowland rice genotypes for zonc uptake efficiency. Scientia Agricola 58:623-626.

Fageria NK, Baligar VC (1993) Screening crop genotypes for mineral stresses. In: Proceeding of the workshop on adaptation of plants to soil stress (INTSORMIL Publication No 94-2) University of Nebraska, Lincoin, Pp. 142-155.

Fageria NK, Baligar VC, Li YC (2008) The role of nutrient efficient plants in improving crop yields in the twenty first century. Journal of Plant Nutrition 31:1121-1157.

Fageria NK, Dos AB, Santos Cobucci T (2011) Zn nutrition of lowland rice. Communication in Soil Science and Plant Annuals 42: 1719-1727.
Figueiredo DD, Barros PM, Cordein AM, Serra TS, Lourenco T, Chander SM, Oliveira MM, Saibo NJ (2012) Seven Zn finger transcription factors use novel regulators of the stress responsive gene of PREBIB. Journal of Experimental Botany 63:3643-3656.

Graham RD, Ascher JS, Hynes SC (1992) Selecting zinc-efficient cereal genotypes for soils of low zinc status. Plant and Soil 146: 241-250.

Graham RD, Humphries JM, Kitchen JL (2000) Nutritionally enhanced cereals: A sustainable foundation for a balanced diet. Asia Pacific Journal of Clinical Nutrition 9: S91-S96.

Graham RD, Knez CM, Welch RM (2012) How much nutritional iron deficiency in human globally is due to an underlying $\mathrm{Zn}$ deficiency. Advances in Agronomy:115:1-40.

Gupta AP (2005) Micronutrient status of and fertilizer use scenario in India. Trace elements in Medical Biology 18: 325-331.

Hacisalihoglu G, Kochian LV (2003) How do some plant tolerate low levels of soil $\mathrm{Zn}$ : Mechanisms of $\mathrm{Zn}$ efficiency in crop plants. New Phytologist 159:341-350.

Hazra GC, Saha B, Saha S, Dusgupta S, Adhikari B, Mandal B (2015) Screening of Rice Cultivars for their Zinc Biofortification Potential in Inceptisols. Journal of Indian Society of Soil Science 63: 347-357.

Impa SM, Morete JM, Ismail MA, Schulin S, Johnson Becbout SE (2013) $\mathrm{Zn}$ uptake, translocation and grain $\mathrm{Zn}$ loading in rice (Oryza sativa L.) genotypes selected for $\mathrm{Zn}$ deficiency tolerance and high grain Zn. Journal of Experimental Botany 64: 27392751. doi:10.1093/ixb/ret118.

Jackson ML (1973) Soil chemical analysis. Prentice Hall of India Pvt.Ltd., New Delhi.

Kumar V, Laik R, Singh SK (2018) Screening of rice (Oryza sativa L.) genotypes for Zinc efficiency under Zinc stress conditions. Journal of Pharmacognosy and Phytochemistry, SPI: 281-283.

Lindsay WL, Norvell WL (1978) Development of DTPA soil test for $\mathrm{Zn}$, iron, manganese and copper. Soil Science Society of America Journal 42:421-428.

Malewar GU, Indulkar BS, Tankankhar VG (1993) Root characteristic and yield attributes as influenced by $\mathrm{Zn}$ levels and groundnut varieties. Annuals of Agricultural Research14:478-481.

Marton DC, Lindsay WL (1990) Testing soil for copper, iron, manganese and zinc. In: Westerman RL (Ed), soil testing and plant analysis, soil science society of America, Madison, Pp. 229-273. 
Olsen SR, Cole CV, Watanabe FF, Bean AL (1945) Estimation of available phosphorus of soil extraction with sodium bicarbonate. U.S. Department Agriculture circular 939:1-19

Rengel Z (2005) Breeding crops for adaptation to environments with low nutrient availability. In: Ashraf M (Ed.) Abiotic stresses: Plant resistance thorough breeding and molecular approaches, The Haworth Press, New York, USA, Pp.239-276.

Sheoran OP, Tonk DS, Kaushik LS, Hasija RC, Pannu RS (1998) Statistical Software package for agricultural Research Workers. In: Hooda, DS, Hasija RC (Eds) Recent Advances in information theory, Statistics \& Computer Applications by Department of Mathematics Statistics, CCS HAU, Hisar, Pp.139-143.

Shukla AK, Behra SK, Pakhara A, Chaudhari SK (2018) Micronutrients in soils, plants, animals and human. Indian Journal of Fertilizers 14: 30-54.

Shukla AK, Tiwari PK, Prakash C (2014) Micronutrient deficiencies vis-à-vis food and nutritional security of India. Indian Journal of Fertilizers 10: 94-112.

Stanford G, English L (1949) Use of the flame photometer in rapid soil tests for K and Ca. Agronomy Journal 4: 446-447.

Subbiah B, Asija G (1956) Alkaline permanganate method of available nitrogen determination. Current Sciences 25: 259.

Sudha S, Stalin P (2015a) Micronutrient content in Rice grains of different Rice Genotypes. Trends in Biosciences 8: 1358-1365.
Sudha S, Stalin P (2015b) Effect of Zn on the yield, quality and grain $\mathrm{Zn}$ content of rice genotypes. International Journal of Farm Sciences, 5:17-27.

Tripathy SK, Dash M, Behera SK, Ithape DM, Maharana M (2017) Nutrient Rich Quality Rice: A Journey to Healthy Life. Advanced Plants and Agricultural Research 7: 00268.

Walkley A, Black IC (1934) An examination of soil organic carbon by chromic acid titration method. Journal of Soil Science 37: 29.

Welch RM (2008) Linkages between trace elements in food crops and human health.p,287-309. In: Alloway BJ (Ed) Micronutrient deficiencies in global crop production. Springer, Dordrech.

White IC, Zasoski RJ (1999) Mapping of soil micronutrients. Field crops Research 60:11-26

White PJ, Broadley MR (2009) Biofortification of crops with seven mineral elements often lacking in human diets-iron, zinc, copper, calcium, magnesium, selenium and iodine. New Phytologist 182: 49-84.

Jin Z, Minyan W, Lianghuan W, Jiangguo W, Chunhai S (2008) Impacts of Combination of Foliar Iron and Boron Application on Iron Biofortification and Nutritional Quality of Rice Grain. Journal of Plant Nutrition 31: 1599 -1611.

Journal of Experimental Biology and Agricultural Sciences

http://www.jebas.org 